\title{
LABOR LAW: EMPLOYEES DISCHARGED FOR REFUSAL TO CROSS PICKET LINE DENIED QUALIFIED RIGHT OF REINSTATEMENT
}

I

I n BALANCING the conflicting legitimate interests of employers and employees, it is established law that employees may be lawfully discharged if their refusal to cross a picket line of another union substantially interferes with the normal business operations of their employer. ${ }^{1}$ In NLRB v. L. G. Everist, Inc., ${ }^{2}$ the Eighth Circuit Court of Appeals rejected an NLRB limitation which would have provided the discharged employees with a qualified right of reinstatement. The court, without articulating whether the employees had been engaged in protected activity, held that the refusal to cross a picket line constituted adequate cause for permanent severance of the employment relationship.

The case arose when four truck drivers refused to cross another union's picket line in the course of delivering materials to another employer's business site. These employees were discharged, and six days later their unconditional applications for reinstatement were rejected even though permanent replacements had not been hired. ${ }^{3}$

The NLRB found that the refusal to reinstate violated section 8 (a) (1) of the Taft-Hartley Act. ${ }^{4}$ Although it held that the refusal to cross the picket line was protected activity, ${ }^{5}$ the Board recognized

2 Teamsters Union v. NLRB, 325 F.2d 1011 (D.C. Cir. 1963), affirming sub nom. Redwing Carriers, Inc., 137 N.L.R.B. 1545 (1962); NLRB v. Rockaway News Supply Co., I97 F.2d 111 (2d Cir. 1952), aff'd on other grounds, 345 U.S. 71 (1953).

2334 F.2d 312 (8th Cir. 1964), enforcing in part, denying in part 142 N.L.R.B. 193 (1963).

Their employer had continued operating his full complement of trucks by temporarily replacing the four discharged drivers with supervisory personnel. Permanent replacements were hired about ten days after the applications for reinstatement were denied. 334 F.2d at 314 .

L. G. Everist, Inc., 145 N.I.R.B. 193, 195 (1963).

Section 8 (a) (1) provides: "It shall be an unfair labor practice for an employer-(1) to interfere with, restrain, or coerce employees in the exercise of the rights guaranteed in section 7; . . Labor Management Relations Act $\$ 8$ (a) (1), 61 Stat. 140 (1947), 29 U.S.C. $\$ 158$ (a) (1) (1958).

Section 7 provides: "Employees shall have the right to self-organization, to form, join, or assist labor organizations ... and to engage in other concerted activities for the purpose of collective bargaining or other mutual aid or protection . . ." Labor Management Relations Act $\S 7,61$ Stat. 140 (1947), 29 U.S.C. § 157 (1958). (Emphasis added.)

142 N.L.R.B. at 195-96.

Not all concerted activities are protected. E.g., International Union, UAW v. 
that an overriding right of the employer to preserve his business justified initial discharge of the drivers, thereby enabling the hiring of replacements. However, it carefully characterized such discharge as merely a permissible act enabling replacement in contrast to a permanent discharge for cause. ${ }^{6}$ The Board concluded that since permanent replacements had not been hired at the time when the claimants unconditionally applied for reinstatement, the employer was obliged to return them to work.

Two members of the Board dissented, ${ }^{7}$ arguing that the refusal to cross the picket line was not protected activity and that the employees were therefore permanently discharged for cause. ${ }^{8}$ The court of appeals, however, did not consider whether the drivers' refusal to cross the picket line constituted protected activity. Its denial of the Board's petition for enforcement of the reinstatement order was instead based on two grounds: ( 1 ) that as applied to the facts of this case, the Board's distinction between discharge for cause and discharge as a permissible act enabling replacement was untenable; ${ }^{9}$ (2) that the employees' violation of their implied obligation to do assigned work justified their permanent discharge. ${ }^{10}$

On both of the above points, the Eighth Circuit relied upon the Supreme Court decision in NLRB v. Rockaway News Supply

Wisconsin Employment Relations Bd., 336 U.S. 245, 257 (1949). Although activities may be concerted in fact, they may fail to be "concerted" within the meaning of $\$ 7$ of the Taft-Hartley Act. See Cox, The Right to Engage in Concerted Activities, 26 IND. L.J. 319 (1951); Note, 1955 U. IL.. L.F. 129. A lawful strike is protected. International Union, UAW v. O'Brien, 339 U.S. 454, 456-57 (1950). A strike is unprotected if it violates federal law or state law which has not been preempted by federal law. International Union, UAW v. Wisconsin Employment Relations Bd., 336 U.S. 245, 259.60 (1949) (discussion of cases where strikes involved sit-downs, mutiny, national emergencies, and violation of contract); see Amalgamated Ass'n of Street Employees v. Wisconsin Employment Relations Bd., 340 U.S. 383 (1951).

- The Board was thus reiterating the rationale of Redwing Carriers, Inc. 137 N.L.R.B. 1545 (1962), affd sub nom., Teamsters Union v. NLRB, 325 F.2d 1011 (D.C. Cir. 1963), which on essentially identical facts allowed discharge by the employer as a permissible act enabling replacement.

I 142 N.L.R.B. at 198-99.

"If an employee's refusal to do his assigned work is unprotected, it constitutes cause for lawful discharge. NLRB v. Kohler Co., 220 F.2d 3 (7th Cir. 1955); NLRB v. Montgomery Ward \& Co., 157 F.2d 486, 497 (8th Cir. 1946).

- 334 F.2d at 316-18.

${ }^{10} \mathrm{Id}$. at 317. The dissenting third member of the court agreed with the NLRB that the drivers were engaged in protected activity and, under the facts in this case, protection included a right to reinstatement prior to permanent replacement. His criticism of the majority opinion was twofold: (I) that it failed to decide the pivotal issue of whether the employees' refusal constituted protected activity; (2) that its authority for rejecting the Board's distinction between discharge for cause and discharge enabling replacement was inapplicable to the present facts. Id. at 318-19. 
Co.11 That case also involved an employee's refusal to cross the picket line of another union. ${ }^{12}$ The Supreme Court refused to decide whether this kind of activity was "protected" by section 7 of the Taft-Hartley Act. ${ }^{13}$ The basis for its decision that the employee was lawfully discharged was that his partial refusal to work violated an express term of his written, union negotiated work contract prohibiting work stoppages except as provided by the contract. ${ }^{14}$ Rockaway News is therefore authority that an employee may expressly contract not to refuse to cross a picket line, and that his breach of the contract constitutes cause for lawful discharge..$^{15}$ Assuming such activity is initially protected, this case says that the protected right to engage in that activity may be bargained away. ${ }^{16}$

Everist, however, extends the rationale of Rockaway News by . declaring that "we see no difference between the refusal to cross a picket line in violation of such a bargaining contract and the refusal to cross a picket line in violation of the ordinary and implied obligations of employment."17 The practical effect of this holding is that when employees enter into an employment relationship, they impliedly contract to perform labor without regard to whether it will necessitate the crossing of picket lines. Refusal to cross a picket, therefore, is a breach of contract justifying permanent discharge. Assuming that such activity is protected by the act, Everist would then stand for the proposition that a right purportedly conferred by statute is effective only if the employee has expressly bargained to preserve the right. Such a rationale tends to render the concept of protected activity nugatory as related to any activity interfering with the performance of one's job. The logical implication of this

12345 U.S. 71 (1953), 29 N.Y.U.L. REv. 758 (1954).

${ }^{12}$ The fact situation in Rockaway News was substantially similar to that in Everist, except for the application for reinstatement. A truck driver employed to pick up and deliver publications at various distribution points was discharged for refusing to make a routine trip to a newspaper plant being picketed by its employees. 345 U.S. at $72-73$.

${ }^{18} I d$, at 75,79 .

14 Id. at $79-81$.

${ }^{18} \mathrm{Id}$. at 80; accord, NLRB v. Sands Mfg. Co., 306 U.S. 332, 344 (1939) (employee breach of employment contract constitutes cause for lawful discharge).

${ }^{16}$ Accord, Mastro Plastics Corp. v. NLRB, 350 U.S. 270, 280, 283 (1955).

${ }_{17} 334$ F.2d at 317 . In this regard, the court liad emphasized at the outset that "at least some" of the nine drivers on this job-had been told when hired that deliveries could not be interrupted by strikes. Id. at 315 . The court did not, however, determine whether the four drivers involved in this case had been so informed. 
holding is that the court did not consider this activity protected ${ }^{18}$ for it is unreasonable to assume as an "ordinary and implied" obligation of employment that the employee has promised not to engage in activity protected by statute.

This decision, therefore, appears contrary to the preponderance of authority which holds that refusal to cross a picket line is protected activity within the meaning of section 7 of the act. Most of these cases have involved refusal by án employee to cross a picket line of his striking co-workers at their common employer's place of business. ${ }^{19}$ There is less precedent for the case where, as in Everist, an employee has refused to cross a picket line formed by employees with whom he has no direct mutuality of interest-most commonly, employees of another employer, picketing at that employer's business site. ${ }^{20}$ Here the refusal has been held "concerted" within the meaning of section 7 of the act because such activity is "in a broad but very real sense directed to mutual aid or protection." 21 The import of this statement is strengthened by the fact that section 2 (9) of the act provides that a "labor dispute" includes any controversy over the terms of employment "regardless of whether the disputants stand in the proximate relation of employer and employee."22 Indeed, the Everist court itself interpreted the Supreme Court decision in Rockaway News as "apparently" affirming that such employee activity is protected. ${ }^{23}$ As an additional consideration, al-

13 The court's statement that "such refusal was no more and no less than a refusal to work" strengthens such an inference. 334 F.2d at 317-18. See note 8 supra.

${ }^{10}$ NLRB v. John S. Swift Co., 277 F.2d 641 (7th Gir. 1960); NLRB v. West Coast Casket Co., 205 F.2d 902 (9th Cir. 1953); NLRB v. Montag Bros., 140 F.2d 730 (5th Cir. 1944); Cinch Mfg. Corp., 91 N.L.R.B. 371 (1950); New York Telephone Co., 89 N.L.R.B. 383 (1950); see Carter Carburetor Corp. v. NLRB, 140 F.2d 714 (8th Cir. 1944).

${ }^{20}$ Teamsters Union v. NLRB, 325 F.2d 1011 (D.C. Cir. 1963), affirming Redwing Carriers, Inc, 137 N.L.R.B. 1545 (1962); NLRB v. Rockaway News Supply Co., 197 F.2d 111 (2d Cir. 1952), aff'd on other grounds, 345 U.S. 71 (1953); Cyril de Cordova \& Brother, 91 N.L.R.B. 1121 (1950). But see, NLRB v. Illinois Bell Tel. Co., 189 F.2d 124 (7th Cir.), cert. denied, 342 U.S. 885 (195I).

${ }^{21}$ NLRB v. Rockaway News Supply Co., 197 F.2d 111-13 (2d Cir. 1952), aff'd on other grounds, 345 U.S. 71 (1953); accord, Redwing Carriers, Inc, 137 N.L.R.B. 1545 (1962), aff'd sub nom. Teamsters Union v. NLRB, 325 F.2d 1011 (D.C. Cir. 1963); Cyril de Cordova \& Brother, 91 N.L.R.B. 1121 (1950); cf. NLRB v. J.G. Boswell Co., 136 F.2d 585, 595-96 (9th Cir. 1943); NLRB v. Peter Cailler Kohler Swiss Chocolates Co., 130 F.2d 503, 505-06 (2d Cir. 1942); Fort Wayne Corrugated Paper Co. v. NLRB, 111 F.2d 869, 873-74 (7th Cir. 1940). But see, NLRB v. Illinois Bell Tel. Co., 189 F.2d 124 (7th Cir.), cert. denied, 342 U.S. 885 (1951).

${ }^{22}$ Labor Management Relations Act $\$ 2(9)$, 61 Stat. 138 (1947), 29 U.S.C. $\$ 152(9)$ (1958); see Cyril de Cordova \& Brother, 91 N.L.R.B. 1121, 1135 (1950).

23334 F.2d at 316 . 
though section 8 (b) (4) of the act prohibits unions from engaging in secondary strikes and boycotts, the proviso to that section expressly declares that nothing therein shall be construed to render unlawful an individual's refusal to cross a picket line around another employer's place of business. ${ }^{24}$ While this proviso does not expressly declare such refusal protected, arguably it indicates Congress' concern lest the provisions of that section be read as denying the act's protection to such refusal. Although the majority in Rockaway News did not consider the merits of this argument, it was expressed by the three dissenting justices as the basis for their opinion that such activity is protected..$^{25}$

If the Eighth Circuit's decision was incorrect by holding in effect that the drivers' refusal was unprotected, nevertheless the court stated in dictum that even if the refusal were assumed protected, there was no right of reinstatement. ${ }^{26}$ Relying upon Rockaway News, the Eighth Circuit rejected the Board's distinction between discharge as a "permissible act enabling replacement" and "discharge for cause,"27 thereby concluding that initial discharge was permanent. In Rockaway News, the NLRB had held that the employee was engaged in protected activity and could not be lawfully discharged, but could only be given an option to perform all his duties or to go on "strike" and make way for his replacement. ${ }^{28}$ In dictum the Supreme Court rejected the distinction between discharge and replacement "in this context" for the reason that it was "not based on any difference in effect upon the employee." 28 In Everist, however, the issue is whether the employee possesses a right to reinstatement. It would make a difference to the employee whether his dismissal was a discharge for cause or an act permitting replacement, if it were found that an incident of the latter is the right to return to work prior to permanent replacement.

\footnotetext{
${ }^{24}$ Labor Management Relations Act \& 8(b) (4), 61 Stat. 141.42 (1947), 29 U.S.C. § 158 (b) (4) (1958).

${ }_{25} 345$ U.S. at $81-82$.

20334 F.2d at 316.

27 Id. at $316-17$.

${ }^{23}$ Rockaway News Supply Co., 95 N.L.R.B. 336, 337 (1951).

${ }^{29} 345$ U.S. at 75 . The Second Circuit had also rejected the distinction on the additional theory that it was unrealistic to assume that an employec would strike as an individual. NLRB v. Rockaway News Supply Co., 197 F.2d 111, 115 (2d Cir. 1952). It nevertheless based its holding that discharge was lawful on the theory that the employee's $\S 7$ rights were limited by the employer's legitimate interest in maintaining shop discipline. Id. at 113.
} 
Since the language in Rockaway News does not resolve this issue, it is necessary to evaluate the Board's distinction in light of the broad policy considerations enunciated in decisions under the TaftHartley Act. Under section 8 (a) (1) of the act, it is an unfair labor practice for an employer to interfere with the right of employees to engage in concerted activity as defined by section 7 of the act. ${ }^{30}$ Although an employee may be lawfully discharged for refusing to perform the tasks for which he was hired, ${ }^{31}$ when the refusal is incident to a "protected activity," discharge for engaging in such activity infringes upon employee rights. ${ }^{32}$ Courts have nevertheless recognized a need to balance "conflicting legitimate interests" of employer and employee. ${ }^{33}$ When it is determined that the employee activity would cause the employer economic and operational hardship "of sufficient moment," 34 the employer may be permitted to deter the adverse effect by resorting to action which, in the language of the Supreme Court, is "saved from illegality by an overriding business purpose justifying the invasion of union rights." 35

A well settled example of such balancing of interests is presented by the economic strike. Although economic strikers are engaged in protected activity, their employer may protect his business operations by replacing the strikers with willing workers. Employees whose positions are thus filled by permanent replacements may be lawfully discharged, but if the striker unconditionally applies for

\footnotetext{
${ }^{80}$ See note 4 supra.

s1 See authorities cited note 8 supra.

${ }^{32}$ E.g., see authorities cited note 19 supra.

${ }^{84}$ NLRB v. Truck Drivers Local 449, 353 U.S. 87, 96 (1957) (multi-employer lockout infringing on $\S 8(a)(1)$ and $8(a)$ (3) rights, nevertheless justified by legitimate employer interest in maintaining group bargaining unity); accord, NLRB v. Erie Resistor Corp., 373 U.S. 221, 232 (1963) " (employer's asserted business purpose insufficient to justify inherently discriminatory super-seniority plan); NLRB v. Floridan Hotel of Tampa, Inc., 318 F.2d 545 (5th Cir. 1963) (employer's legitimate business interests not substantially injured by employees' protected activity of wearing small union buttons); American Brake Shoe Co. v. NLRB, 244 F.2d 489 (7th Cir. 1957) (employer's slowdown and layoff, while detrimental to employee bargaining efforts, justified by his legitimate interest in preventing irreparable harm to his business).

34 American Brake Shoe Co. v. NLRB, supra note 33, at 493.

${ }^{85}$ NLRB v. Erie Resistor Corp., 373 U.S. 221, 231 (1963). The Court described its task to be "weighing the interests of employees in concerted activity against the interest of the employer in operating his business in a particular manner and of balancing in the light of the Act and its policy the intended consequences upon employee rights against the business ends to be served by the employer's conduct." 1d. at 229. The court here held the employer's asserted business purpose insufficient to insulate his discriminatory super-seniority plan from the reach of $\S 8(a)(1)$ and 8 (a) (3). Id. at 232.
} 
reinstatement prior to permanent replacement, he retains the right to return to the equivalent of his former position..$^{38}$

Within the context of the Everist case, therefore, it would appear that the distinction drawn by the NLRB between discharge for cause and discharge as a permissible act enabling replacement is supported both in law and policy. If the employee who refuses to cross a picket line in the course of employment has engaged in protected activity ${ }^{37}$ substantially interfering with his employer's business, the employer, for purposes of maintaining his business operations, may discharge his employee in order to hire a replacement. If the employee unconditionally applies for reinstatement prior to permanent replacement, his interests are easily reconciled with the legitimate interest of the employer which originally justified discharge-maintaining business operations. ${ }^{38}$ In view of the courts' concern for balancing conflicting legitimate interests, ${ }^{30}$ it is logical to conclude that when theretofore legitimate interests no longer conflict, a reconciliation should be effected. ${ }^{40}$ Disregard of this con-

${ }^{88}$ NLRB v. Mackay Radio \& Telegraph Co., 304 U.S. 333, 345.46 (1938); NLRB v. Globe Wireless, Ltd., 193 F.2d 748 (9th Cir. 1951); NLRB v. Remington Rand, Inc, 130 F.2d 919, 927-28 (2d Cir. 1942).

Contrast the situations where, because one side has engaged in an unfair labor practice, there are no conflicting legitimate interests. When employees strike in protest of an employer's unfair labor practice, reinstatement is an absolute right. NLRB v. United Brass Works, 287 F.2d 689, 695 (4th Cir. 1961). Similarly, permanent discharge is lawful when employees distupt business operations by engaging in activity which is unprotected. See, e.g., International Union, UAW v. Wisconsin Employment Relations Bd., 336 U.S. 245 (1949) (intermittent, unannounced work stoppages to win unstated concessions); NLRB v. Sands Mfg. Co., 306 U.S. 332 (1939) (strike in contravention of a collective bargaining agreement); NLRB v. Fansteel Metallurgical Corp., 306 U.S. 240 (1939). See also note 5 supra.

${ }^{8 \pi}$ See text accompanying notes $19-25$ supra.

ss This reasoning, although unarticulated by the Board, seems inherent in its concluding language. "In light of its continued need for e'mployees, the Respondent's argument that it was seeking to replace the claimants in order to operate its business fails and its refusal to reinstate them because of their refusal to cross a picket line necessarily constitutes a penalty for engaging in that protected activity." $\mathrm{L}$. G. Everist, Inc., 142 N.L.R.B. 199, $195-96$ (1963).

${ }^{80}$ See note 33 supra.

${ }^{\circ}$ The NLRB's conclusion that the drivers were entitled to reinstatement was based upon the similarity of their position to that of economic strikers, who are entitled to reinstatement prior to permanent replacement. L. G. Everist, Inc, 142 N.L.R.B. 193, 195 (1963). It may be argued that the analogy is inappropriate in that economic strikers have been held entitled to reinstatement because they remain employees until replacement occurs. See NLRB v. Remington Rand, Inc., 130 F.2d 919, 927-28 (2d Cir. 1942). Nevertheless, it is arguable that the claimants in Everist remain "employees" within the meaning of $\S 2(3)$ of the act because their work has ceased in connection with a current labor dispute. See Labor Management Relations Act $\S 2(3), 61$ Stat. 137-38 (1947), 29 U.S.C. § 152(3) (1958). In a broader sense, any 
sideration in Everist irrevocably and unrealistically confines the consideration of conflicting legitimate interests to the date of discharge.

attempt to determine the merits of the reinstatement question by arguing whether the claimants remain "employees" overlooks the initial justification for their discharge, and would determine substantive rights and duties in labor law on purely verbal distinctions; in both situations the employees had engaged in protected activity, were out of work, and sought reinstatement. See NLRB v. Rockaway News Supply Co., 345 U.S. 71, 75 (1953). 